\title{
Effect of Process Parameters on the Photocatalytic Degradation of Phenol in Oilfield Produced Wastewater using $\mathrm{ZnO} / \mathrm{Fe}_{2} \mathrm{O}_{3}$ Nanocomposites
}

\author{
Omer Al Haiqi ${ }^{1, *}$, Abdurahman Hamid Nour ${ }^{1}$, Rushdi Bargaa ${ }^{1}$, Bamidele Victor Ayodele ${ }^{2}$ \\ ${ }^{1}$ Faculty of Chemical and Process Engineering Technology, College of Engineering Technology, \\ Universiti Malaysia Pahang, Lebuhraya Tun Razak, Gambang-Kuantan 26300, Malaysia. \\ ${ }^{2}$ Institute of Energy Policy and Research, Universiti Tenaga Nasional, Jalan IKRAM-UNITEN, 4300 \\ Kajang, Malaysia.
}

Received: $8^{\text {th }}$ October 2019; Revised: $5^{\text {th }}$ November 2019; Accepted: $5^{\text {th }}$ November 2019; Available online: 28th February 2020; Published regularly: April 2020

\begin{abstract}
The upstream processing of crude oil is often associated with the presence of phenolic compounds when not properly treated could result in adverse effects on human health. The objective of the study was to investigate the effect of process parameters on the photocatalytic degradation of phenol. The $\mathrm{ZnO} / \mathrm{Fe}_{2} \mathrm{O}_{3}$ nanocomposite photocatalyst was prepared by sol-gel method and characterized using various instrument techniques. The characterized $\mathrm{ZnO} / \mathrm{Fe}_{2} \mathrm{O}_{3}$ nanocomposite displayed suitable physicochemical properties for the photocatalytic reaction. The $\mathrm{ZnO} / \mathrm{Fe}_{2} \mathrm{O}_{3}$ nanocomposite was employed for the phenol degradation in a cylindrical batch reactor under solar radiation. The photocatalytic runs show that calcination temperature of the $\mathrm{ZnO} / \mathrm{Fe}_{2} \mathrm{O}_{3}$ nanocomposite, catalyst loading, initial phenol concentration and $\mathrm{pH}$ of the wastewater significantly influence the photocatalytic degradation of phenol. After 180 min of solar radiation, the highest phenol degradation of $92.7 \%$ was obtained using the $\mathrm{ZnO} / \mathrm{Fe}_{2} \mathrm{O}_{3}$ photocatalyst calcined at $400{ }^{\circ} \mathrm{C}$. This study has demonstrated that phenol degradation is significantly influenced by parameters such as calcination temperature of the $\mathrm{ZnO} / \mathrm{Fe}_{2} \mathrm{O}_{3}$ nanocomposite, catalyst loading, initial phenol concentration and $\mathrm{pH}$ of the wastewater resulting in highest phenol degradation using the $\mathrm{ZnO} / \mathrm{Fe}_{2} \mathrm{O}_{3}$ nanocomposite calcined at $400{ }^{\circ} \mathrm{C}$, initial phenol concentration of $0.5 \mathrm{mg} / \mathrm{L}$, catalyst loading of $3 \mathrm{mg} / \mathrm{L}$ and $\mathrm{pH}$ of 3. Copyright $\subset 2020$ BCREC Group. All rights reserved
\end{abstract}

Keywords: Degradation; Photocatalyst; Phenol; Wastewater; $\mathrm{ZnO} / \mathrm{Fe}_{2} \mathrm{O}_{3}$ nanocomposites

How to Cite: Al Haiqi, O., Nour, A.H., Bargaa, R., Ayodele, B.V. (2020). Effect of Process Parameters on the Photocatalytic Degradation of Phenol in Oilfield Produced Wastewater using $\mathrm{ZnO} / \mathrm{Fe}_{2} \mathrm{O}_{3} \mathrm{Nano}$ composites. Bulletin of Chemical Reaction Engineering \& Catalysis, 15(1), 128-136

(doi:10.9767/bcrec.15.1.6068.128-136)

Permalink/DOI: https://doi.org/10.9767/bcrec.15.1.6068.128-136

\section{Introduction}

The processing of crude oil in onshore facilities is often accompanied by the use of a huge amount of water [1]. This produced wastewater usually contains some toxic pollutants that if not properly treated before disposal could

* Corresponding Author.

Email: omaralhaigi@gmail.com (O. Al Haiqi) threaten human health [2]. Besides, in the arid region such as the middle east where there is a high shortage of water, effective treatment of the produced wastewater to meet the stipulated standard can make it be re-used for agricultural purposes [3]. One of such toxic chemicals that need to be properly removed from the produced wastewater is phenol [4]. The United States Environmental Protection Agency (EPA) has 
branded phenol as one of the priority pollutants in wastewater that needs urgent attention due to its high risk to human health even at very low concentrations [5]. Hence, strict limits regarding the concentration of phenol allowed in wastewater have been set by various international regulatory agencies, such as EPA [6,7]. Based on the EPA standard, the concentration of phenol in treated wastewater must not exceed 1 part per billion (ppb) [5]. Exposure of wastewater containing phenol concentration between $9-15 \mathrm{mg} / \mathrm{L}$ could lead to serious health problems [8].

Techniques, such as: biodegradation, physical separation, and advanced oxidation process, have been employed for the treatment of wastewater targeting the removal of recalcitrant pollutants [9-11]. Amongst these techniques used for the treatment of wastewater containing phenolic compounds, advance oxidation process has been reported as an efficient strategy. Moradi et al. [12] employed irondoped $\mathrm{TiO}_{2}$ for the degradation of phenol and reported 57\% phenol removal from the wastewater. In a similar study by Zhang et al. [13], Co- $\mathrm{Pd} / \mathrm{BiVO}_{4}$ photocatalyst was employed for the degradation of phenol under visible light irradiation. The degradation of 90\% phenol was attained after 180 min of visible light irradiation. The variation in the amount of phenol degraded in Moradi et al. [12] and Zhang et $a l$. [13] can be attributed to the variation in the physicochemical properties of the photocatalysts and the differences in the process parameters. Recently, the use of nanocomposite photocatalysts, such as: $\mathrm{AgBr} / \mathrm{BiOBr} /$ graphene, $\mathrm{Bi}$ $\mathrm{OCl}-\mathrm{TiO}_{2}, \mathrm{ZnO} / \mathrm{Nd}$-doped $\mathrm{BiOBr}$, and $\mathrm{Ag}-\mathrm{ZnO}$ for the photocatalytic degradation of phenol under visible light, have been reported [14-17]. These studies revealed that phenol was effectively degraded from the wastewater using the nanocomposite photocatalysts. In the present study $\mathrm{ZnO} / \mathrm{Fe}_{2} \mathrm{O}_{3}$ nanocomposite synthesized by sol-gel was employed for the degradation of phenol in produce wastewater obtained from an onshore oil wastewater treatment facility. The effect of $\mathrm{ZnO} / \mathrm{Fe}_{2} \mathrm{O}_{3}$ nanocomposite calcination temperature, catalyst loading, initial phenol concentration and the $\mathrm{pH}$ of the wastewater on the phenol degradation was investigated.

\section{Materials and Methods}

The sample of the produced water used for the experimentation was obtained from the produced wastewater treatment plant, Masila, Yemen. The water sample was stored in an airtight dark bottle and refrigerated before using for the experimental runs. The initial concentration of phenol was determined from the water sample.

The $\mathrm{ZnO} / \mathrm{Fe}_{2} \mathrm{O}_{3}$ nanocomposite photocatalyst was prepared using precursors materials, such as: zinc nitrate hexa-hydrate $\left(\mathrm{Zn}\left(\mathrm{NO}_{3}\right)_{2} .6 \mathrm{H}_{2} \mathrm{O}, 99.999 \%\right.$ trace metal bases, Sigma-Aldrich), iron (III) nitrate nonahydrate $\left(\mathrm{Fe}\left(\mathrm{NO}_{3}\right)_{3} .9 \mathrm{H}_{2} \mathrm{O}, 99.999 \%\right.$ trace metal bases, Sigma-Aldrich), ethanol (90\% by volume), ethylene glycol (99.8\% purity), hydrochloric acid (99.8\% purity), and citric acid (99.5\% purity). Sol-gel method standards for the synthesis of the $\mathrm{ZnO} / \mathrm{Fe}_{2} \mathrm{O}_{3}$ photocatalyst [18]. To prepare the photocatalyst, $\mathrm{Zn}\left(\mathrm{NO}_{3}\right)_{2} \cdot 6 \mathrm{H}_{2} \mathrm{O}$ and $\mathrm{Fe}\left(\mathrm{NO}_{3}\right)_{3} .9 \mathrm{H}_{2} \mathrm{O}$ were dissolved in a beaker containing $100 \mathrm{ml}$ ethanol in a molar ratio of $1: 3$ and stirred for 30 min using a magnetic stirrer. A $3 \mathrm{~mol}$ of citric acid and $50 \mathrm{ml}$ ethanol was prepared separately and added to the colloidal gel-like salt-solution. The entire mixture was subsequently stirred continuously at $60{ }^{\circ} \mathrm{C}$ on a hot plate for $60 \mathrm{~min}$. This enables the completion of the hydrolysis and condensation with the addition of $\mathrm{NH}_{3}$ and $\mathrm{HCl}$ occasionally to regulate the $\mathrm{pH}$ of the gel. Thereafter the obtained gel was allowed to dry in an oven at 80 ${ }^{\circ} \mathrm{C}$ for $40 \mathrm{~min}$ to form a xerogel which was calcined $400{ }^{\circ} \mathrm{C}$ for $3 \mathrm{~h}$ to obtain the $\mathrm{ZnO} / \mathrm{Fe}_{2} \mathrm{O}_{3}$ nanocomposite photocatalyst. The crystallinity, the textural properties, the morphology and the photo-properties of the $\mathrm{ZnO} / \mathrm{Fe}_{2} \mathrm{O}_{3}$ photocatalysts were examined by X-ray Diffractometer (XRD), Field Emission Scanning Electron Microscope (FESEM), $\mathrm{N}_{2}$ physisorption analysis and UV/Vis spectrophotometer.

\subsection{Phenol Degradation}

The as-prepared $\mathrm{ZnO} / \mathrm{Fe}_{2} \mathrm{O}_{3}$ nanocomposite was tested for photo-degradation of phenol in the produced wastewater under direct solar radiation. The effects of parameters such as $\mathrm{ZnO} / \mathrm{Fe}_{2} \mathrm{O}_{3}$ calcination, phenol initial concentration, photocatalyst loading, and $\mathrm{pH}$ of the produced wastewater on phenol degradation was examined. A cylindrical batch reactor (non-concentrating type slurry reactor) was employed for the photodegradation experimental runs. For each of the experimental runs, $100 \mathrm{~mL}$ of the produced wastewater was used together with the specified amount of $\mathrm{ZnO} / \mathrm{Fe}_{2} \mathrm{O}_{3}$ nanocomposite ranges from 0.5-3 $\mathrm{mg} / \mathrm{L}$ was added to the oil field produced water and continuously stirred under dark for 60 minutes. The produced water containing the photocatalyst was placed under direct solar radiation to commence the photodegradation re- 
action. About 0.5 to $1.0 \mathrm{~mL}$ of the aliquot was collected at 15-minutes interval after the commencement of the experimental runs. The aliquot was centrifuged and filtered. The concentration of the phenol left in the treated produce water was measured using High-performance Liquid Chromatography (486-WFMA HPLC). The extent of photocatalytic degradation of the phenol in the produced wastewater was calculated using Equation (1):

$$
D E \%=\frac{C_{0}-C}{C_{0}} \times 100
$$

where $C_{0}$ is the initial concentration at $t=0$ and $C$ is the concentration of toxic compounds at different intervals of irradiation time, $t=$ $t_{\min }$.

\section{Results and Discussion}

3.1 Characterization of the $\mathrm{ZnO} / \mathrm{Fe}_{2} \mathrm{O}_{3}$ Nanocatalyst

Figure 1 depicts the XRD pattern of the $\mathrm{ZnO} / \mathrm{Fe}_{2} \mathrm{O}_{3}$ nanocomposite photocatalyst. The

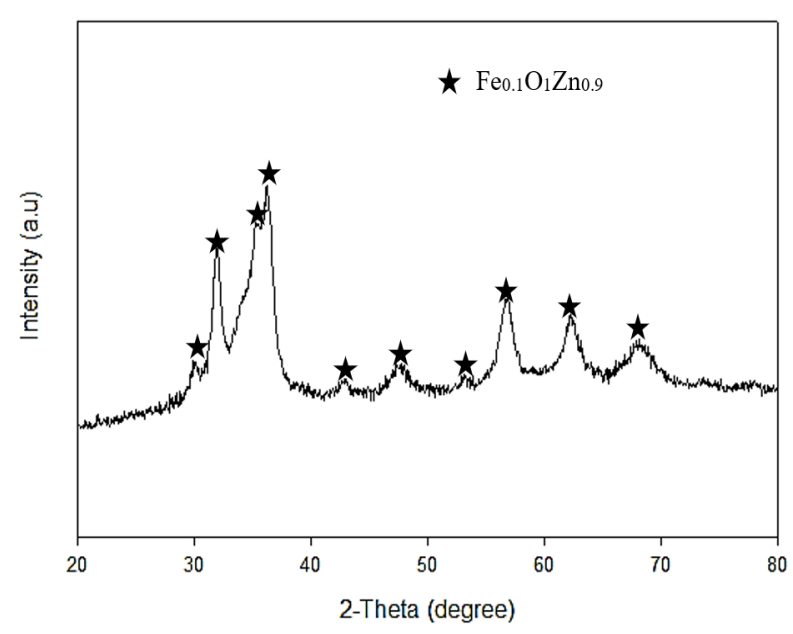

Figure 1. XRD pattern of the $\mathrm{ZnO} / \mathrm{Fe}_{2} \mathrm{O}_{3}$ nanocomposite.

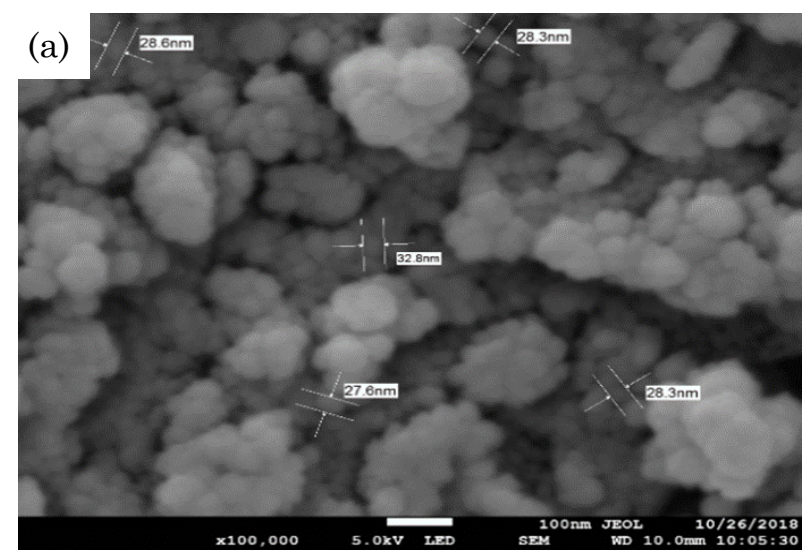

XRD pattern shows reflective peaks well indexed at 2 -theta values of $29.94^{\circ}, 31.89^{\circ}, 34.32^{\circ}$, $35.98^{\circ}, 44.28^{\circ}, 48.78^{\circ}, 56.65^{\circ}, 58.32^{\circ}, 62.22^{\circ}$, and $67.78^{\circ}$ to the hexagonal structure of $\mathrm{Fe}_{0.1} \mathrm{O}_{1} \mathrm{Zn}_{0.9}$ nanocomposite with International Centre for Diffraction Data (ICDD) no of 98008-9727 [19]. The XRD pattern did not capture $\mathrm{ZnO}$ and $\mathrm{Fe}_{2} \mathrm{O}_{3}$ which implies that the oxides were aggregated to form $\mathrm{Fe}_{2.02} \mathrm{O}_{4} \mathrm{Zn}_{0.96}$ nanocomposite [20].

The $\mathrm{N}_{2}$ physisorption analysis of the $\mathrm{ZnO} / \mathrm{Fe}_{2} \mathrm{O}_{3}$ nanocomposites showing the adsorption-desorption isotherm is depicted in Figure 2. The adsorption isotherm displayed a typical Type IV adsorption isotherm with the H3-hysteresis loop in accordance with the International Union of Pure and Applied Chemistry (IUPAC) classifications [21,22]. This is an indication of weakly adsorption of liquid $\mathrm{N}_{2}$ onto the surface of the $\mathrm{ZnO} / \mathrm{Fe}_{2} \mathrm{O}_{3}$ nanocomposites with evidence of capillary condensation occurring in photocatalyst mesopore [23]. The Brunauer-Emmett-Teller (BET) specific surface area and the Berrett-Joyner-Halenda

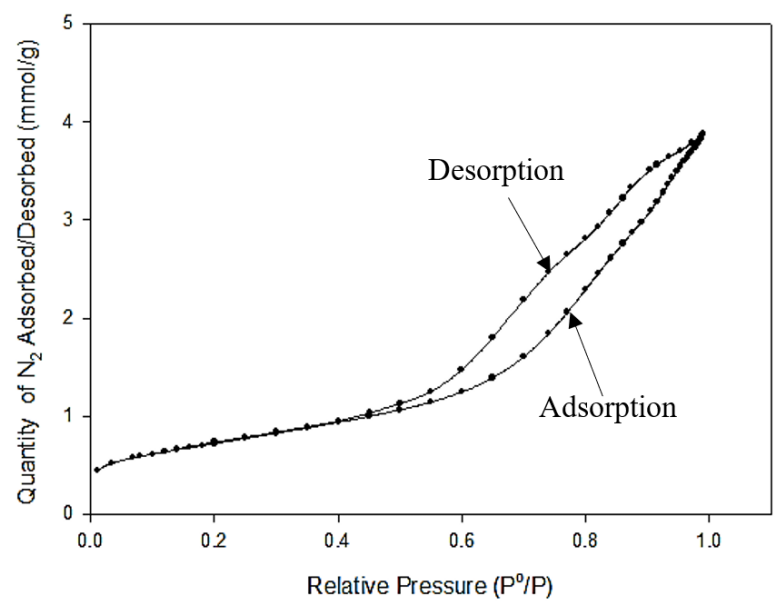

Figure 2. Adsorption-Desorption isotherm of the $\mathrm{ZnO} / \mathrm{Fe}_{2} \mathrm{O}_{3}$ nanocomposite.

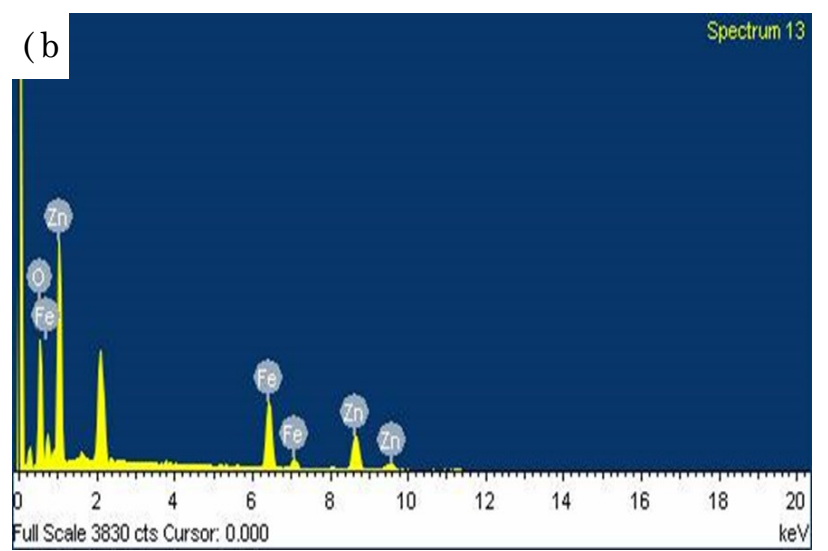

Figure 3. (a) The FESEM images and (b) EDX micrographs of the $\mathrm{ZnO} / \mathrm{Fe}_{2} \mathrm{O}_{3}$ nanocomposite. 
(BJH) pore volume of the $\mathrm{ZnO} / \mathrm{Fe}_{2} \mathrm{O}_{3}$ nanocomposites are estimated as $57.64 \mathrm{~m}^{2} / \mathrm{g}$ and 0.137 $\mathrm{cm}^{3} / \mathrm{g}$, respectively. The pore diameter of the $\mathrm{ZnO} / \mathrm{Fe}_{2} \mathrm{O}_{3}$ photocatalyst was obtained as 9.34 $\mathrm{nm}$ which further confirms the mesoporous nature of the $\mathrm{ZnO} / \mathrm{Fe}_{2} \mathrm{O}_{3}$ nanocomposites since a mesoporous material has an average pore diameter greater than $2 \mathrm{~nm}$ [24].

Figure 3 depicted the FESEM image and the EDX micrograph showing the morphology and the elemental composition of the $\mathrm{ZnO} / \mathrm{Fe}_{2} \mathrm{O}_{3}$ photocatalyst. The FESEM image revealed a spherical cluster of $\mathrm{ZnO} / \mathrm{Fe}_{2} \mathrm{O}_{3}$ nanocomposites as shown in Figure 3 (a). The average particle size of the nanocomposite taken at five different points was calculated as $29.12 \mathrm{~nm}$. An evidence of agglomeration of the spherical nanocomposites can be observed which might have occurred during the calcination process. The detail elemental composition of the $\mathrm{ZnO} / \mathrm{Fe}_{2} \mathrm{O}_{3}$

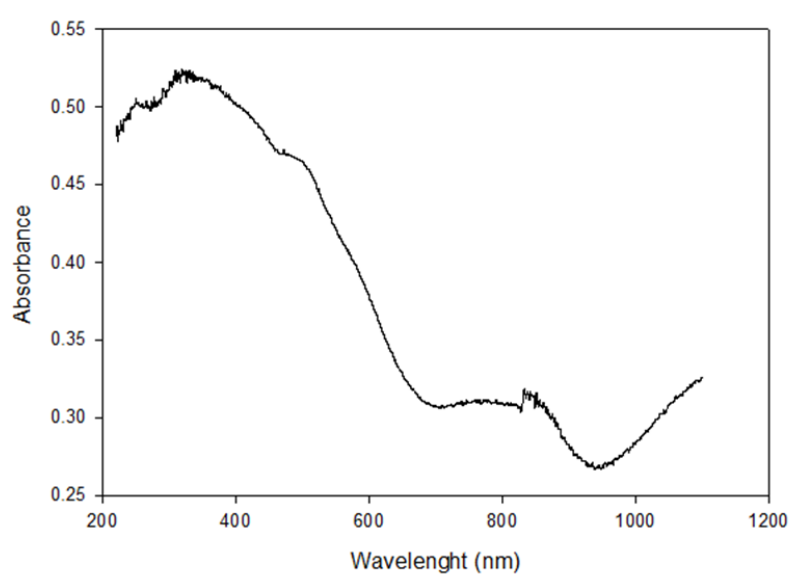

Figure 4. UV-vis absorption spectra for the $\mathrm{ZnO} / \mathrm{Fe}_{2} \mathrm{O}_{3}$ nanocomposite.

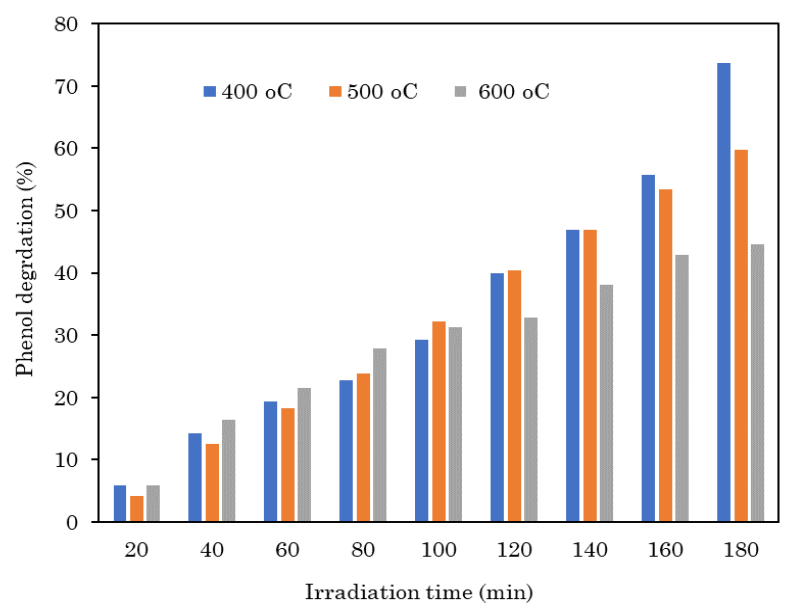

Figure 5. Degradation of phenol for $\mathrm{ZnO} / \mathrm{Fe}_{2} \mathrm{O}_{3}$ calcined at $400{ }^{\circ} \mathrm{C}$, $500 \quad{ }^{\circ} \mathrm{C}$, and $600{ }^{\circ} \mathrm{C}$ (Photocatalyst amount: $1 \mathrm{mg} / \mathrm{L}$, phenol concentration of $0.5 \mathrm{mg} / \mathrm{L}$ ). nanocomposites is represented in Figure 3 (b). The different elements such as $\mathrm{Zn}, \mathrm{O}$, and Fe which make up the photocatalyst are well represented by the EDX micrograph which further establishes the suitability of the sol-gel method used for preparing the $\mathrm{ZnO} / \mathrm{Fe}_{2} \mathrm{O}_{3}$ photocatalyst [25].

Figure 4 shows the UV-vis absorption spectra of the $\mathrm{ZnO} / \mathrm{Fe}_{2} \mathrm{O}_{3}$ photocatalyst. It can be seen that the $\mathrm{ZnO} / \mathrm{Fe}_{2} \mathrm{O}_{3}$ photocatalyst exhibited absorption peaks in both the ultra-violet and the visible regions as indicated by the wavelength range. This revealed the suitability of the $\mathrm{ZnO} / \mathrm{Fe}_{2} \mathrm{O}_{3}$ nanocomposites as photocatalyst that can be employed for degradation of phenol using enormous potential solar energy resources in the visible light region.

\subsection{Effect of Process Parameters on the Photo-} degradation of Phenol

\subsubsection{Photocatalyst calcination temperature}

The effect of varying calcination temperature on the photocatalytic activities of the $\mathrm{ZnO} / \mathrm{Fe}_{2} \mathrm{O}_{3}$ photocatalyst using $1-2 \mathrm{mg} / \mathrm{L}$ of the photocatalysts as well as 0.5 and $3 \mathrm{mg} / \mathrm{L}$ of the phenol concentration are depicted in Figure 5 and 6. In Figure 5, it can be seen that the degradation of the phenol in the produced wastewater increases with an increase in the irradiation time for each of the $\mathrm{ZnO} / \mathrm{Fe}_{2} \mathrm{O}_{3}$ photocatalysts calcined at $400{ }^{\circ} \mathrm{C}, 500{ }^{\circ} \mathrm{C}$, and 600 ${ }^{\circ} \mathrm{C}$ using $1 \mathrm{mg} / \mathrm{L}$ of the photocatalyst and 0.5 $\mathrm{mg} / \mathrm{L}$ of the phenol concentration. However, at irradiation time less than $120 \mathrm{~min}$, the degradation of phenol was higher with $\mathrm{ZnO} / \mathrm{Fe}_{2} \mathrm{O}_{3}$ photocatalysts calcined at $500{ }^{\circ} \mathrm{C}$ and $600{ }^{\circ} \mathrm{C}$

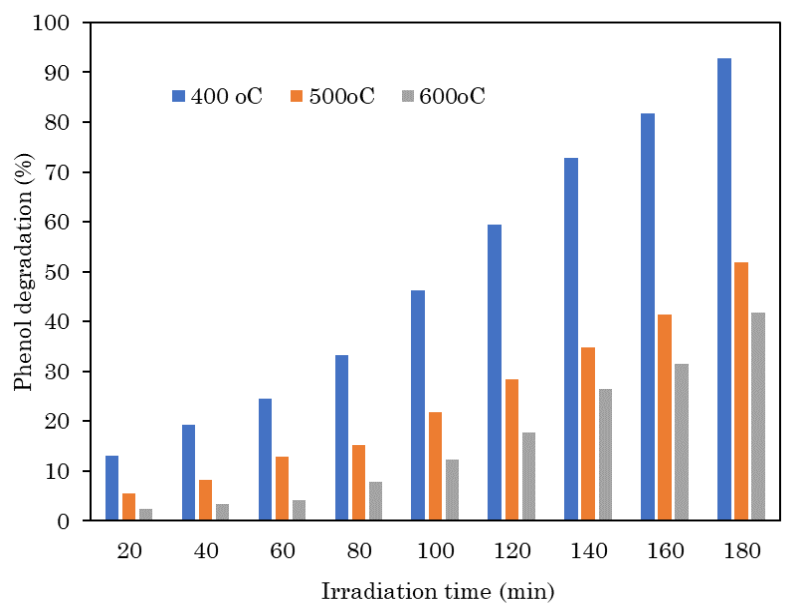

Figure 6. Degradation of phenol for calcined at $400{ }^{\circ} \mathrm{C}, \quad 500{ }^{\circ} \mathrm{C}$, and $600{ }^{\circ} \mathrm{C}$ (Photocatalyst amount: $2 \mathrm{mg} / \mathrm{L}$, phenol concentration of 3 $\mathrm{mg} / \mathrm{L})$. 
compared to the $\mathrm{ZnO} / \mathrm{Fe}_{2} \mathrm{O}_{3}$ photocatalysts calcined at $400{ }^{\circ} \mathrm{C}$. This trend could be attributed to non-steady uptake of the phenol probably due to its low concentration. As time progresses, there was a steady adsorption of the phenol from the wastewater. This observation was only peculiar to low concentration of phenol. After 180 mins photodegradation of the phenol under solar radiation, $73.6 \%, 59.8 \%$, and $44.6 \%$ of the phenol have been degraded by the $\mathrm{ZnO} / \mathrm{Fe}_{2} \mathrm{O}_{3}$ photocatalyst calcined at $400{ }^{\circ} \mathrm{C}, 500{ }^{\circ} \mathrm{C}$, and $600{ }^{\circ} \mathrm{C}$, respectively. This implies that the photodegradation of the phenol is strongly dependent on the calcination temperature of the photocatalyst. Interestingly, the highest phenol degradation from the produced wastewater was obtained using the $\mathrm{ZnO} / \mathrm{Fe}_{2} \mathrm{O}_{3}$ photocatalyst calcined at $400{ }^{\circ} \mathrm{C}$. This agrees with the work of Kangle et al. [26] who reported the effect of cal-

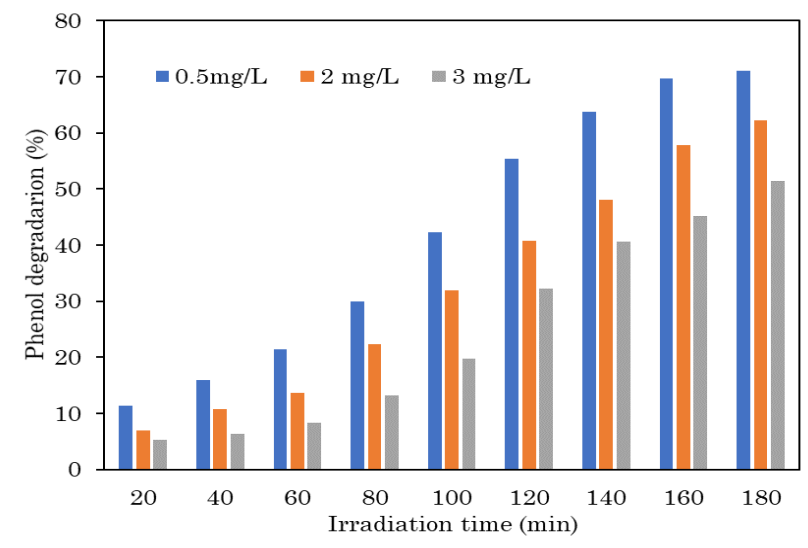

Figure 7. Degradation of phenol at different initial phenol concentration $\left(\mathrm{ZnO} / \mathrm{Fe}_{2} \mathrm{O}_{3}\right.$ calcined at $400{ }^{\circ} \mathrm{C}$ and photocatalyst loading of 2 $\mathrm{mg} / \mathrm{L}$ and $\mathrm{pH}=3$ ).

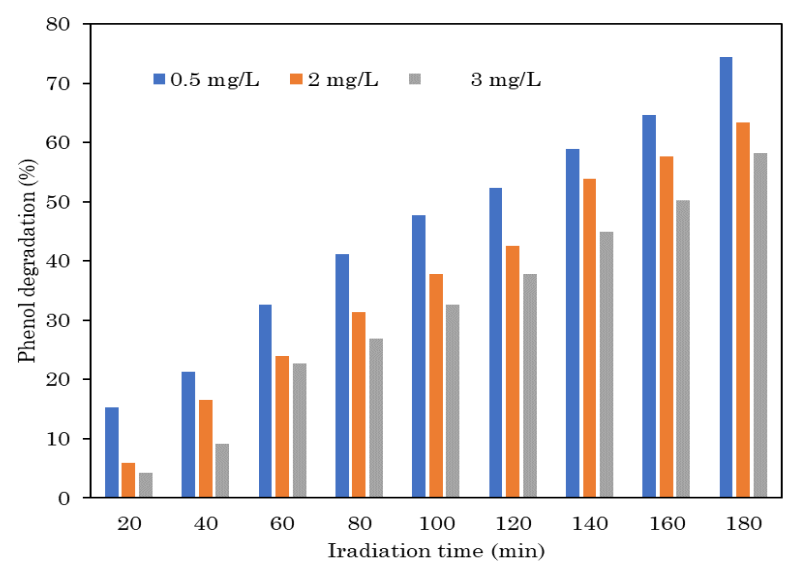

Figure 8. Degradation of phenol at different phenol initial concentration $\left(\mathrm{ZnO} / \mathrm{Fe}_{2} \mathrm{O}_{3}\right.$ calcined at $500{ }^{\circ} \mathrm{C}$, photocatalyst loading of 2 $\mathrm{mg} / \mathrm{L}, \mathrm{pH}=3$ ). cination of the photocatalytic activity of $\mathrm{TiO}_{2}$ used for degrading surface fluorine. Obviously, an increase in calcination temperature probably has effects on the pores of the photocatalysts indicated by the cumulative pore volume of $0.137 \mathrm{~cm}^{3} / \mathrm{g}, 0.127 \mathrm{~cm}^{3} / \mathrm{g}, 0.078 \mathrm{~cm}^{3} / \mathrm{g}$ for calcination temperature of $400{ }^{\circ} \mathrm{C}, 500{ }^{\circ} \mathrm{C}$, and 600 ${ }^{\circ} \mathrm{C}$, respectively. The pores of the photocatalysts are responsible for the adsorption of the phenol prior to photodegradation reaction. Moreover, the increase, in calcination temperature could also lead to decrease in the BET surface areas $\left(57.65 \mathrm{~m}^{2} / \mathrm{g}, 20.72 \mathrm{~m}^{2} / \mathrm{g}\right.$, and 7.67 $\mathrm{m}^{2} / \mathrm{g}$ for calcination temperature of $400{ }^{\circ} \mathrm{C}, 500$ ${ }^{\circ} \mathrm{C}$, and $600{ }^{\circ} \mathrm{C}$, respectively) which could be responsible for the decrease in photocatalytic activity as reported by Xiao and Ouyang [27]. Also, the effect of varying calcination temperature on the photocatalytic activity using a higher photocatalyst amount of $2 \mathrm{mg} / \mathrm{L}$ and phenol concentration of the $3 \mathrm{mg} / \mathrm{L}$ is depicted in Figure 6. Similarly, the activity of the photocatalyst decreases with increases in the calcination temperature. After $180 \mathrm{~min}$ irradiation time, the $92.7 \%, 41.4 \%$, and $41.7 \%$ of the phenol in the produced wastewater have been degraded using the $\mathrm{ZnO} / \mathrm{Fe}_{2} \mathrm{O}_{3}$ photocatalyst calcined at $400{ }^{\circ} \mathrm{C}, 500{ }^{\circ} \mathrm{C}, 600{ }^{\circ} \mathrm{C}$, respectively. With increase in the phenol concentration and the amount of photocatalyst, the amount of phenol degraded in the produced wastewater also increases using $\mathrm{ZnO} / \mathrm{Fe}_{2} \mathrm{O}_{3}$ photocatalyst calcined at $400{ }^{\circ} \mathrm{C}$. These results suggest that attaining high phenol degradation requires the use of $\mathrm{ZnO} / \mathrm{Fe}_{2} \mathrm{O}_{3}$ photocatalyst calcined at a temperature around $400{ }^{\circ} \mathrm{C}$. Comparing Figure 5 and 6 on the bases of the amount of photocatalyst used and the concentration of the phe-

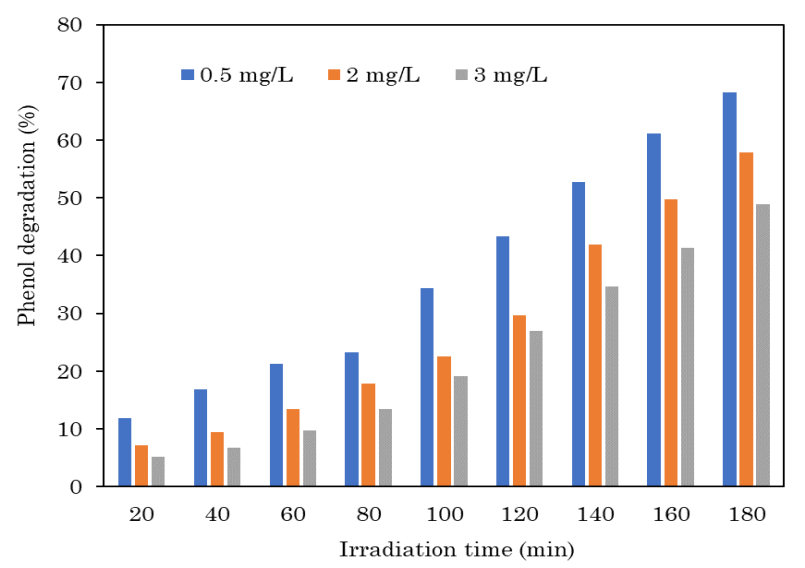

Figure 9. Degradation of phenol under at different phenol initial concentration $\left(\mathrm{ZnO} / \mathrm{Fe}_{2} \mathrm{O}_{3}\right.$ calcined at $600{ }^{\circ} \mathrm{C}$, photocatalyst load of 2 $\mathrm{mg} / \mathrm{L}, \mathrm{pH}=3$ ). 
nol, it can be seen that a more steady degradation of the phenol was observed using $1 \mathrm{mg} / \mathrm{L}$ of the $\mathrm{ZnO} / \mathrm{Fe}_{2} \mathrm{O}_{3}$ photocatalysts calcined at 400 ${ }^{\circ} \mathrm{C}, 500{ }^{\circ} \mathrm{C}, 600{ }^{\circ} \mathrm{C}$ and phenol concentration of $0.5 \mathrm{mg} / \mathrm{L}$ compared to using $2 \mathrm{mg} / \mathrm{L}$ of $\mathrm{ZnO} / \mathrm{Fe}_{2} \mathrm{O}_{3}$ photocatalyst calcined at $400{ }^{\circ} \mathrm{C}$, $500{ }^{\circ} \mathrm{C}, 600{ }^{\circ} \mathrm{C}$ for $3 \mathrm{mg} / \mathrm{L}$ of phenol concentration. Nevertheless, the highest phenol degradation was recorded using $2 \mathrm{mg} / \mathrm{L}$ of the $\mathrm{ZnO} / \mathrm{Fe}_{2} \mathrm{O}_{3}$ photocatalyst calcined at $400{ }^{\circ} \mathrm{C}$ and phenol concentration of $3 \mathrm{mg} / \mathrm{L}$.

\subsubsection{Effect of initial phenol concentration}

The effect of initial phenol concentration on the degradation of phenol using $\mathrm{ZnO} / \mathrm{Fe}_{2} \mathrm{O}_{3}$ photocatalyst calcined at $400{ }^{\circ} \mathrm{C}, 500{ }^{\circ} \mathrm{C}$, and $600{ }^{\circ} \mathrm{C}$ are shown in Figures $7-9$, respectively. In Figure 7, $2 \mathrm{mg} / \mathrm{L}$ of the $\mathrm{ZnO} / \mathrm{Fe}_{2} \mathrm{O}_{3}$ photocatalyst calcined at $400{ }^{\circ} \mathrm{C}$ was employed for the photodegradation of the phenol in the produced water. It can be seen that the photodeg-

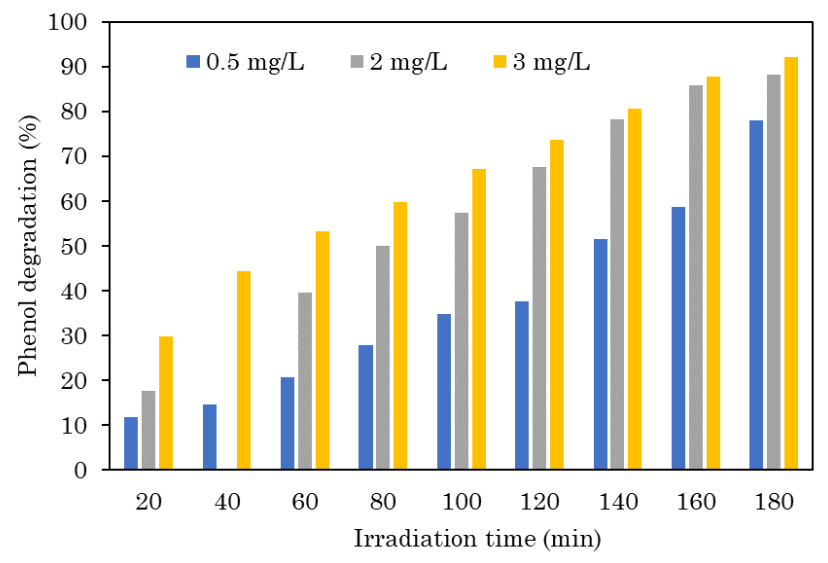

Figure 10. Degradation of phenol at varying amount of $\mathrm{ZnO} / \mathrm{Fe}_{2} \mathrm{O}_{3}$ calcined at $400{ }^{\circ} \mathrm{C}$ (Phenol initial concentration of $3 \mathrm{mg} / \mathrm{L} ; \mathrm{pH}=3$ ).

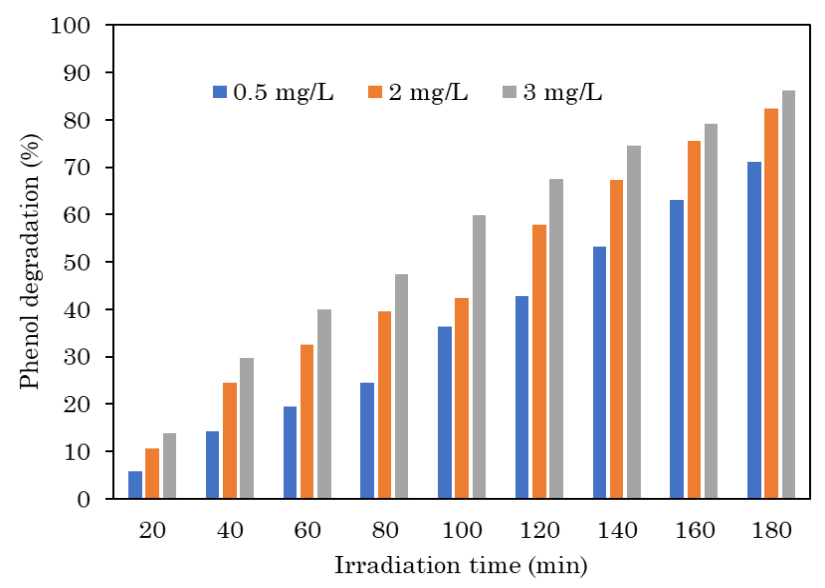

Figure 11. Degradation of phenol at varying amount of $\mathrm{ZnO} / \mathrm{Fe}_{2} \mathrm{O}_{3}$ calcined at $500{ }^{\circ} \mathrm{C}$ (Phenol initial concentration of $3 \mathrm{mg} / \mathrm{L} ; \mathrm{pH}=3$ ). radation of the phenol decreases with an increase in the initial phenol concentration. After $180 \mathrm{~min}$ of solar radiation, $71.1 \%, 62.3 \%$, and $51.5 \%$ of phenol were degraded from the produced water at $0.5,2$, and $3 \mathrm{mg} / \mathrm{L}$ initial phenol concentration, respectively. Also, in Figure 8, 2 $\mathrm{mg} / \mathrm{L}$ of the $\mathrm{ZnO} / \mathrm{Fe}_{2} \mathrm{O}_{3}$ photocatalyst calcined at $500{ }^{\circ} \mathrm{C}$ was employed for the photodegradation of the phenol in the produced water. The photodegradation of the phenol varies with the initial phenol concentration in the produced water. After $180 \mathrm{~min}, 74.5 \%, 63.4 \%$, and $58.2 \%$ of the phenol present in produced water have been degraded from the produced water with the initial phenol concentration of at $0.5,2$, and $3 \mathrm{mg} / \mathrm{L}$, respectively. Similar, Figure 9 shows the variation of the amount of phenol degraded using different initial phenol concentration. Phenol degradation was $68.3 \%, 57.8 \%$, and $48.9 \%$ after 180 mins using at $0.5,2$, and 3 $\mathrm{mg} / \mathrm{L}$ initial phenol concentration. Muhammad et al. [28] reported that a higher phenol concentration often leads to low phenol degradation efficiency which is in agreement with trend obtained in this study. The present study is consistent with that of Paul et al. [29] who reported that g- $_{3} \mathrm{~N}_{4}$ photocatalyst at various loading significantly influences the photodegradation of methylene blue in contaminated water. The presence of high concentration of phenol in the solution entails more time to attain the same removal rate as the low concentration of phenol, hence gives rise to low phenol degradation efficiency.

\subsubsection{Effect of photocatalyst loading}

Figures 10-12 show the effect of photocatalyst loading on the phenol degradation using photocatalyst calcined at $400{ }^{\circ} \mathrm{C}, 500{ }^{\circ} \mathrm{C}$, and

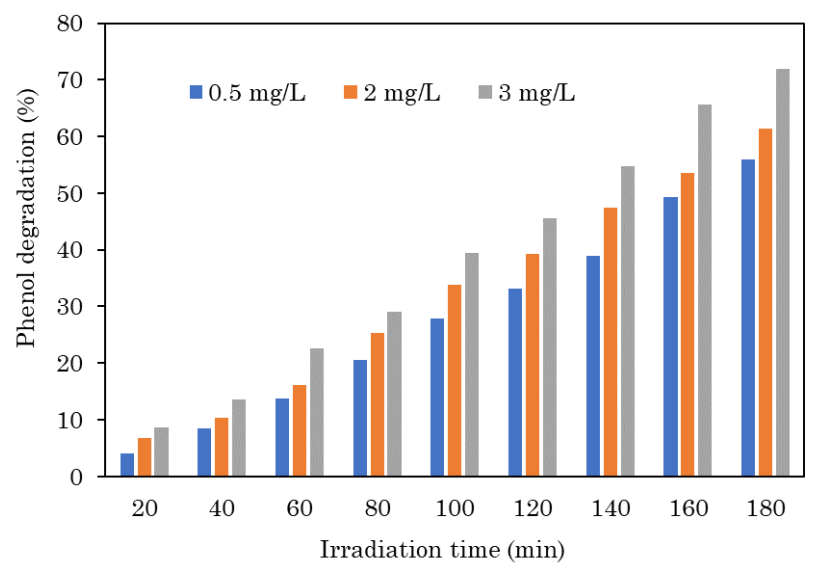

Figure 12. Degradation of phenol at varying a mount of $\mathrm{ZnO} / \mathrm{Fe}_{2} \mathrm{O}_{3}$ calcined at $600{ }^{\circ} \mathrm{C}$ (Phenol initial concentration of $3 \mathrm{mg} / \mathrm{L} ; \mathrm{pH}=3$ ). 
$600{ }^{\circ} \mathrm{C}$, respectively. The amount of the photocatalyst was varied from 0.5 to $3 \mathrm{mg} / \mathrm{L}$. Figure 10 depicts the photodegradation of phenol at different photocatalyst loading (the photocatalyst was calcined at $400{ }^{\circ} \mathrm{C}$ ). It can be seen that the photodegradation of the phenol increases with an increase in the photocatalyst loading [30]. After $180 \mathrm{~min}, 77.9 \%, 88.2 \%$, and $92.2 \%$ have been degraded from the produced water using photocatalyst loading of $0.5 \mathrm{mg} / \mathrm{L}, 2$ $\mathrm{mg} / \mathrm{L}$, and $3 \mathrm{mg} / \mathrm{L}$, respectively. A similar trend was observed for the photocatalyst calcined at $500{ }^{\circ} \mathrm{C}$ used at various loading for the photodegradation reaction. The degradation of the phenol in the produced wastewater increase with the photocatalyst loading. Phenol degradation of $71.2 \%, 82.4 \%$, and $86.2 \%$ were obtained for photocatalyst loading of $0.5 \mathrm{mg} / \mathrm{L}, 1$

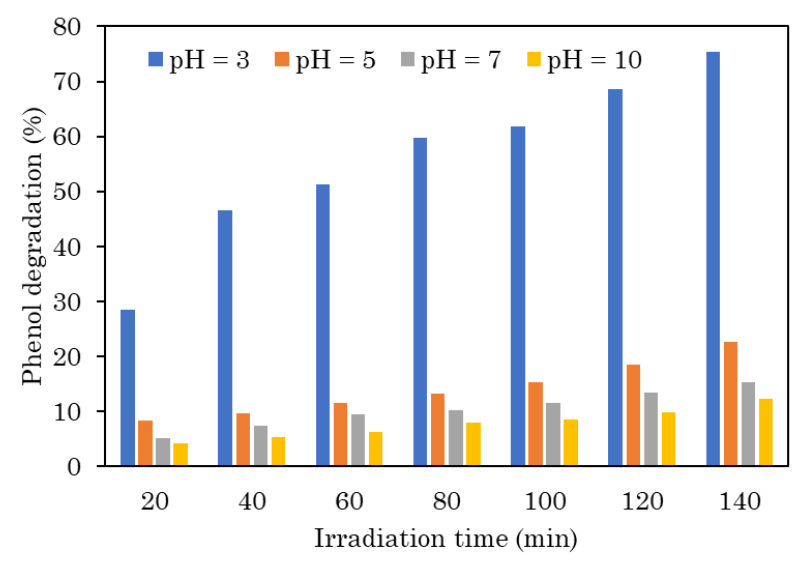

Figure 13. Degradation of phenol at varying $\mathrm{pH} \quad\left(\mathrm{ZnO} / \mathrm{Fe}_{2} \mathrm{O}_{3}\right.$ calcined at $\left.400{ }^{\circ} \mathrm{C}\right)$ (photocatalyst load $3 \mathrm{mg} / \mathrm{L}$ and phenol initial concentration $3 \mathrm{mg} / \mathrm{L}$ ).

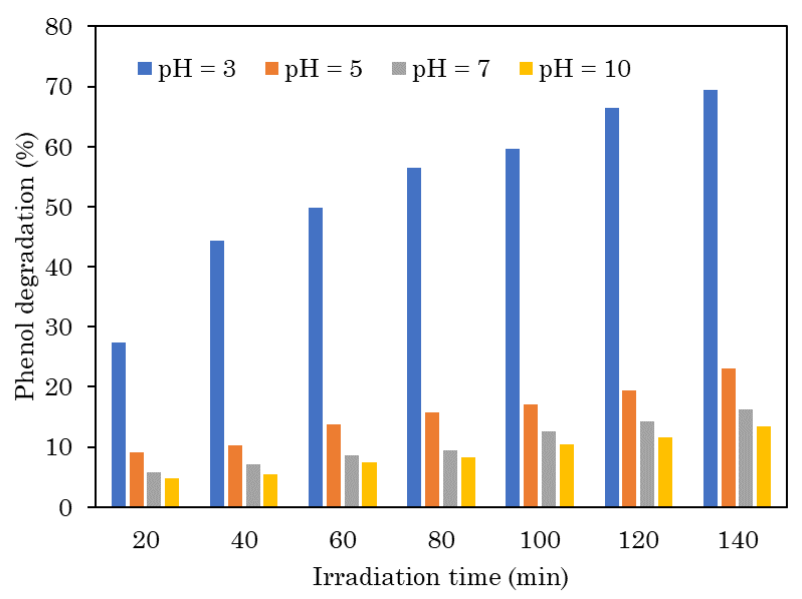

Figure 14. Degradation of phenol at varying $\mathrm{pH} \quad\left(\mathrm{ZnO} / \mathrm{Fe}_{2} \mathrm{O}_{3}\right.$ calcined at $\left.500 \quad{ }^{\circ} \mathrm{C}\right)$ (photocatalyst load: $3 \mathrm{mg} / \mathrm{L}$ and phenol initial concentration $3 \mathrm{mg} / \mathrm{L}$ ). $\mathrm{mg} / \mathrm{L}$, and $3 \mathrm{mg} / \mathrm{L}$, respectively after $180 \mathrm{~min}$ of solar radiation. Moreover, the photodegradation of phenol using the photocatalyst calcined at $600{ }^{\circ} \mathrm{C}$ followed the same trend with the amount phenol degraded in the produced wastewater increases with increase in the photocatalyst loading. $55.9 \%, 61.4 \%$, and $71.9 \%$ of the phenol degraded using $0.5 \mathrm{mg} / \mathrm{L}, 2 \mathrm{mg} / \mathrm{L}$, and $3 \mathrm{mg} / \mathrm{L}$ of the photocatalyst, respectively.

\subsubsection{Effect of $\mathrm{pH}$}

The effect of $\mathrm{pH}$ on the photocatalytic degradation of phenol using $\mathrm{ZnO} / \mathrm{Fe}_{2} \mathrm{O}_{3}$ photocatalyst calcined at a temperature range of $400-600{ }^{\circ} \mathrm{C}$ is depicted in Figures 13-15. Studies have shown that photocatalytic degradation of recalcitrant pollutants is often affected by the $\mathrm{pH}$ of the solution [29]. Figure 10 depicts the effect of $\mathrm{pH}$ on the photodegradation of phenol in produce water using $\mathrm{ZnO} / \mathrm{Fe}_{2} \mathrm{O}_{3}$ calcined at $400{ }^{\circ} \mathrm{C}$. The initial $\mathrm{pH}$ solution of the produced wastewater was set at $3,5,7$, and 10 which covers acidic, neutral and alkaline solution. It is obvious that the amount of phenol degraded from the produced wastewater decreases with increase in the $\mathrm{pH}$ of the water. After $180 \mathrm{~min}$ of solar radiation, $75.3 \%, 22.6 \%, 15.2 \%$, and $12.3 \%$ of phenol was degraded from the produced wastewater with $\mathrm{pH}$ of $3,5,7$, and 10 respectively. This implies that the formation of radicals needed to adsorb on the surface of the photocatalyst is facilitated in the acidic medium as displayed in this study. A similar observation was observed using $\mathrm{ZnO} / \mathrm{Fe}_{2} \mathrm{O}_{3}$ photocatalyst calcined at $500{ }^{\circ} \mathrm{C}$ for the degradation of phenol in the produced wastewater depicted in Figure 14. At $180 \mathrm{~min}, 69.5 \%$, 23.1\%, 16.3\%

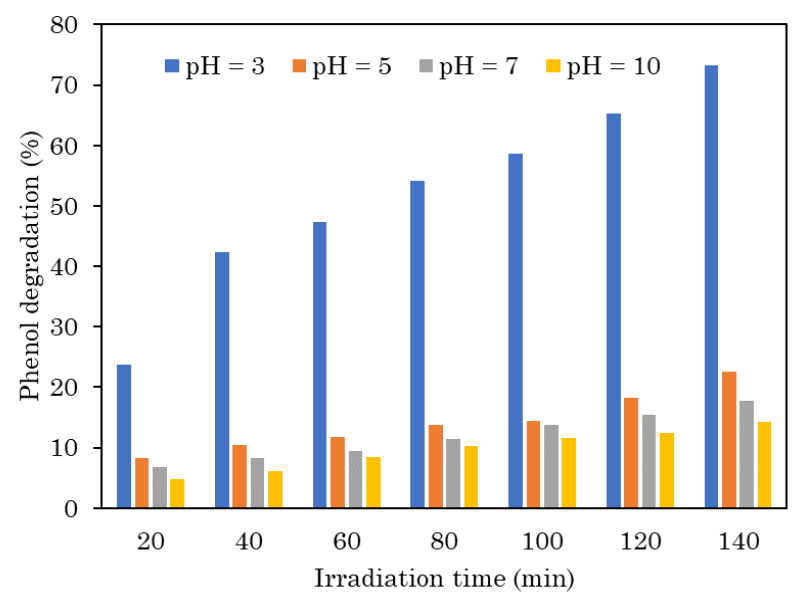

Figure 15. Degradation of phenol at varying $\mathrm{pH}\left(\mathrm{ZnO} / \mathrm{Fe}_{2} \mathrm{O}_{3}\right.$ calcined at $600{ }^{\circ} \mathrm{C}$, catalyst loading: $3 \mathrm{mg} / \mathrm{L}$ and phenol initial concentration: $3 \mathrm{mg} / \mathrm{L}$ ). 
and $13.5 \%$ phenol have been degraded from the produced wastewater with $\mathrm{pH}$ of $3,5,7$, and 10 respectively. For the $\mathrm{ZnO} / \mathrm{Fe}_{2} \mathrm{O}_{3}$ calcined at 600 ${ }^{\circ} \mathrm{C}$, similar trend was also observed for the degradation of phenol in the produced water at different $\mathrm{pH}$ values. In the produced wastewater with $\mathrm{pH}$ of $3,5,7$ and 10 , the photocatalytic process resulted in the degradation of $73.3 \%$, $22.6 \%, 17.7 \%$, and $14.2 \%$, respectively.

\section{Conclusion}

In this study, the effects of parameters, such as: $\mathrm{ZnO} / \mathrm{Fe}_{2} \mathrm{O}_{3}$ nanocomposite calcination temperature, catalyst loading, initial phenol concentration, and $\mathrm{pH}$ of the wastewater on the phenol degradation, have been investigated. For each of the parameters considered, the amount of phenol degradation was found to increase with the irradiation time. Hence, the three parameters were found to significantly influence the amount of phenol degraded from the wastewater. The amount of phenol degradation was found to increase with an increase in the photocatalyst loading but decrease with increase in calcination temperature and $\mathrm{pH}$ of the wastewater. The maximum phenol degradation was attained using $\mathrm{ZnO} / \mathrm{Fe}_{2} \mathrm{O}_{3}$ nanocomposite photocatalyst calcined at $400{ }^{\circ} \mathrm{C}$, initial phenol concentration of $0.5 \mathrm{mg} / \mathrm{L}$, catalyst loading of $3 \mathrm{mg} / \mathrm{L}$ and $\mathrm{pH}$ of 3 . The combination of these parameters can further be optimized for efficient photodegradation of the phenol from the produced wastewater.

\section{References}

[1] Gonzalez, R., Scarlat, N. (2020). Overview of the Water Requirements for Energy Production in Africa, in: V. Naddeo, M. Balakrishnan, K.-H. Choo (Eds.). Front. Frontiers in Water-Energy-Nexus - Nature-Based Solutions, Advanced Technologies and Best Practices for Environmental Sustainability. Cham, Switzerland. Springer International Publishing 417-420. DOI: 10.1007/978-3-030-130688_104

[2] Liang, Y., Ning, Y., Liao, L., Yuan, B. (2018). Special Focus on Produced Water in Oil and Gas Fields: Origin, Management, and Reinjection Practice, in: B. Yuan, D.A. Wood (Eds.), Formation Damage During Improved Oil Recovery. Houston, Texas. Gulf Professional Publishing. 515-586. DOI: 10.1016/B978-0-12-813782-6.00014-2

[3] Zehtabiyan-Rezaie, N., Alvandifar, N., Saffaraval, F., Makkiabadi, M., Rahmati, N., Saffar-Avval, M. (2019). A solar-powered solution for water shortage problem in arid and semi- arid regions in coastal countries. Sustainable Energy Technologies and Assessments, 35, 111. DOI: 10.1016/j.seta.2019.05.015

[4] Liu, F. (2019). Polyaniline/MWCNT Nanocomposite as Sensor for Electroanalytical Determination of Phenol in Oil Field Wastewater. International Journal of Electrochemical Science, 14, 9122-9131. DOI: 10.20965/2019.09.79

[5] Environmental Protection Agency (2002). Toxicological Review for Phenol. http://www.epa.gov/iris.

[6] World Health Organization (1994). Phenol Health and safety Guide No. 88. https://apps.who.int/iris/handle/10665/39958

[7] Environmental Protection Agency (2000). Phenol.

https://www.epa.gov/sites/production/files/201 6-09/documents/phenol.pdf.

[8] Bruce, R.M., Santodonato, J., Neal, M.W. (1987). Summary review of the health effects associated with Phenol. Toxicology Industrial. Health, 3(4), 535-568. DOI: $10.1177 / 074823378700300407$

[9] Villegas, L.G.C., Mashhadi, N., Chen, M., Mukherjee, D., Taylor, K.E., Biswas, N.A. (2016). Short Review of Techniques for Phenol Removal from Wastewater. Current Pollution Reports, 2(3), 157-167. DOI:10.1007/s40726-016-0035-3.

[10] Ke, Q., Zhang, Y., Wu, X., Su, X., Wang, Y., Lin, H., Mei, R., Zhang, Y., Hashmi, M.Z. Chen, C., Chen, J. (2018). Sustainable biodegradation of phenol by immobilized Bacillus sp. SAS19 with porous carbonaceous gels as carriers. Journal of Environmental Management, 222, 185-189. D O I : 10.1016/j.jenvman.2018.05.061.

[11] Fernandes, A., Makoś, P., Khan, J.A., Boczkaj, G. (2019). Pilot scale degradation study of 16 selected volatile organic compounds by hydroxyl and sulfate radical based advanced oxidation processes. Journal of Cleaner. Production, 208, 54-64. DOI: 10.1016/j.jclepro.2018.10.081.

[12] Moradi, V., Ahmed, F., Jun, M.B.G., Blackburn, A., Herring, R.A. (2019). Acid-treated Fe-doped $\mathrm{TiO}_{2}$ as a high performance photocatalyst used for degradation of phenol under visible light irradiation. Journal of Environmental Science, 83, 183-194. DOI: 10.1016/j.jes.2019.04.002.

[13] Zhang, Y., Gao, B., Lu, L., Yue, Q., Wang, Q., Jia, Y. (2010). Treatment of produced water from polymer fl ooding in oil production by the combined method of hydrolysis acidification-dynamic membrane bioreactor - coagula- 
tion process. Journal of Petroleum Science and Engineering, 74, 14-19. DOI: 10.1016/j.petrol.2010.08.001.

[14] Vaiano, V., Matarangolo, M., Murcia, J.J., Rojas, H., Navío, J.A., Hidalgo, M.C. (2018). Enhanced photocatalytic removal of phenol from aqueous solutions using $\mathrm{ZnO}$ modified with Ag. Applied Catalysis B: Environmental, 225, 197-206. DOI:10.1016/j.apcatb.2017.11.075.

[15] Sin, J-.C., Lim, C-.A., Lam, S-.M., Mohamed, A.R., Zeng, H. (2019). Facile synthesis of novel $\mathrm{ZnO} / \mathrm{Nd}$-doped $\mathrm{BiOBr}$ composites with boosted visible light photocatalytic degradation of phenol. Material Letters, 248, 20-23. DOI: 10.1016/j.matlet.2019.03.129.

[16] Singh, P., Raizada, P., Sudhaik, A., Shandilya, P., Thakur, P., Agarwal, S., Gupta, V.K. (2019). Enhanced photocatalytic activity and stability of $\mathrm{AgBr} / \mathrm{BiOBr} / g r a p h e n e ~ h e t e r o j u n c-$ tion for phenol degradation under visible light, Journal of Saudi Chemical Society, 23, 586-599. DOI: 10.1016/j.jscs.2018.10.005.

[17] Sánchez-Rodríguez, D., Medrano, M.G.M., Remita, H., Escobar-Barrios, V. (2018) Photocatalytic properties of $\mathrm{BiOCl}-\mathrm{TiO}_{2}$ composites for phenol photodegradation. Journal of Environmental Chemical Engineering, 6, 16011612. DOI: 10.1016/j.jece.2018.01.061.

[18] Tao, X., Li, X., Huang, L., Wang, G., Ye, Q. (2016). Highly active $\mathrm{Ni}-\mathrm{Ce} / \mathrm{TiO}_{2}-\mathrm{Al}_{2} \mathrm{O}_{3}$ catalysts: Influence of preparation methods. International Journal of Hydrogen Energy, 41(15), 6271-6276. DOI:

10.1016/j.ijhydene.2016.03.031.

[19] Aliah, H., Syarif, D.G., Iman, R.N., Sawitri, A., Darmalaksana, W., Setiawan, A., Malik, A. Gumarang, P. (2019). Structure Analysis of Nanocomposite $\mathrm{ZnO}: \mathrm{Fe}_{2} \mathrm{O}_{3}$ based Mineral Yarosite as $\mathrm{Fe}_{2} \mathrm{O}_{3}$ Source and its Application Probability. Material Today Proceedings, 13, 36-40. DOI: 10.1016/j.matpr.2019.03.183.

[20] Xie, J., Zhou, Z., Lian, Y., Hao, Y., Li, P., Wei, Y. (2015). Synthesis of a - $\mathrm{Fe}_{2} \mathrm{O}_{3} / \mathrm{ZnO}$ composites for photocatalytic degradation of pentachlorophenol under UV-vis light irradiation. Ceramics International, 41, 2622-2625. DOI: 10.1016/j.ceramint.2014.10.043.

[21] Sing, K.S.W., Williams, R.T. (2004). Physisorption Hysteresis Loops and the Characterization of Nanoporous Materials. Adsorption Science and Technology, 22, 773-782. DOI: 10.1260/0263617053499032.

[22] Donohue, M., Aranovich, G., (1998). Classification of Gibbs adsorption isotherms. $A d$ vances in Colloid and Interface Science, 7677, 137-152. DOI: 10.1016/S00018686(98)00044-X.
[23] Groen, J.C., Peffer, L.A., Pérez-Ramirez, J. (2003). Pore size determination in modified micro- and mesoporous materials. Pitfalls and limitations in gas adsorption data analysis, Microporous Mesoporous Materials, 60, 117. DOI: 10.1016/S1387-1811(03)00339-1.

[24] Huang, B., Bartholomew, C.H., Woodfield, B.F. (2014). Improved calculations of pore size distribution for relatively large, irregular slit-shaped mesopore structure. Microporous Mesoporous Materials, 184, 112-121. DOI: 10.1016/j.micromeso.2013.10.008.

[25] Benrabaa, R., Löfberg, A., Guerrero Caballero, J., Bordes-Richard, E., Rubbens, A., Vannier, R-N., Boukhlouf, H., Barama, A. (2015). Sol-gel synthesis and characterization of silica supported nickel ferrite catalysts for dry reforming of methane. Catalysis Communication, 58, 127-131. D O I : 10.1016/j.catcom.2014.09.019.

[26] Lv, K., Xiang, Q., Yu, J. (2011). Effect of calcination temperature on morphology and photocatalytic activity of anatase $\mathrm{TiO}_{2}$ nanosheets with exposed $\{001\}$ facets. Applied Catalysis B: Environmental, 104, 275-281. DOI: 10.1016/j.apcatb.2011.03.019.

[27] Xiao, Q., Ouyang, L. (2009). Photocatalytic activity and hydroxyl radical formation of carbon-doped $\mathrm{TiO}_{2}$ nanocrystalline: Effect of calcination temperature. Chemical Engineering Journal, 148, 248-253. DOI: 10.1016/j.cej.2008.08.024.

[28] Muhammad, S., Saputra, E., Sun, H., Izidoro, J.D.C., Fungaro, D.A., Ang, H.M., Tadé, M.O., Wang, S. (2012). Coal fly ash supported $\mathrm{Co}_{3} \mathrm{O}_{4}$ catalysts for phenol degradation using peroxymonosulfate. RSC Advances, 2, 5645-5650. DOI: $10.1039 / \mathrm{c} 2 \mathrm{ra} 20346 \mathrm{~d}$.

[29] Paul, T., Das, D., Das, B.K., Sarkar, S., Maiti, S., Chattopadhyay, K.K. (2019). $\mathrm{CsPbBrC}_{12} / \mathrm{g}$ $\mathrm{C}_{3} \mathrm{~N}_{4}$ type II heterojunction as efficient visible range photocatalyst. Journal of Hazardous Materials, 380, 120855 . DOI: 10.1016/j.jhazmat.2019.120855.

[30] Ayodele, B.V., Khan, M.R., Nooruddin, S.S., Cheng, C.K. (2017). Modelling and optimization of syngas production by methane dry reforming over samarium oxide supported cobalt catalyst: response surface methodology and artificial neural networks approach. Clean Technologies and Environmental Policy, 19(4), 1181-1193. 